\title{
Beyond the Protestantism of Political Theology: The Politics of Theological Voluntarism
}

\author{
Anver Emon \\ Version Publisher's Version \\ Citation Anver M. Emon "Beyond the Protestantism of Political Theology: \\ (published version) Thinking the Politics of Theological Voluntarism" [2016] 29:2 Studies in \\ Christian Ethics 190 - 203. \\ Publisher's Statement Anver M. Emon "Beyond the Protestantism of Political Theology: \\ Thinking the Politics of Theological Voluntarism" [2016] 29:2 Studies in \\ Christian Ethics 190 - 203. \\ Copyright (C [2016]. Reprinted by permission of SAGE Publications.
}

How to cite TSpace items

\begin{abstract}
Always cite the published version, so the author(s) will receive recognition through services that track citation counts, e.g. Scopus. If you need to cite the page number of the author manuscript from TSpace because you cannot access the published version, then cite the TSpace version in addition to the published version using the permanent URI (handle) found on the record page.
\end{abstract}

This article was made openly accessible by $U$ of $T$ Faculty. Please tell us how this access benefits you. Your story matters. 


\section{Beyond the Protestantism of Political Theology: Thinking the Politics of Theological Voluntarism}

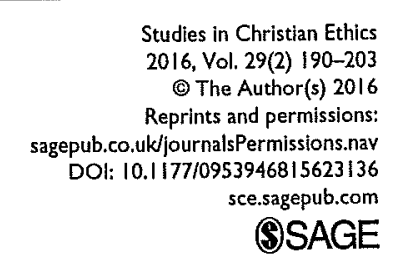

\section{Anver M. Emon}

University of Toronto, Canada

\section{Abstract}

In an attempt to think through the Islamic alongside the Christian, this article draws upon the political theology of Carl Schmitt to reflect on the salience of sovereignty. But in doing so, the article re-reads Schmitt's political theology for its Protestant voluntarism, and adopts a more robust theological voluntarism as a vehicle for reflecting on political thought across both Christian and Islamic history. Moreover, this approach to political theology makes possible reflections on how political theology, whether in Christian or Islamic thought, may offer a critical lens by which to gain new analytic insights into the operation of sovereignty in presumably secularised regimes of thought, such as international law.

\section{Keywords}

Carl Schmitt, international law, Islam, political theology, sovereignty, voluntarism

Robin Lovin begins his essay briefly pondering counterfactuals, one in particular considering what would have become of Islam and the Muslim community if, instead of forming a polity in Medina and expanding Islamic suzerainty through conquest, the early band of Muslims became explorers and preachers, traversing the globe but without a land to call home $(d \bar{a} r)$. He writes: 'What would Islam be like if the hijra in $622 \mathrm{CE}$ had led the Prophet and his successors to traverse the Byzantine and Persian empires as missionaries and teachers, instead of founding an Islamic polity in Medina?' ' Lovin's playful

1. Robin Lovin, 'Authority, Legitimacy, and Sovereignty: Religion and Politics in the Roman Empire before Constantine', Studies in Christian Ethics 29.2 (May 2016), p. 178. counterfactual offers a useful point of departure for this response essay, as we collectively consider in this project, New Conversations in Islamic and Christian Political Thought, concerning the various possibilities that lie within the long and deep intellectual history of Christianity and Islam.

To posit that counterfactual in this way calls into question the secular presumptions that distinguish between faith on the one hand, and political community on the other. In fact, the counterfactual, among other things, recognises the inevitability of politics in the very formation of religious community, and thereby showcases how religion- no less than gender, race or class - is an intersected category of analysis. That such a claim must be made is perhaps due to an intellectual inheritance in which disciplines such as history or politics are presumed to be secular. But to presume them as secular is not merely to distinguish the political from the religious as if these categories were already known; rather to presume the secularity of such disciplines is to construct and to reinstantiate the political and the religious as distinguishable categories. It is perhaps because, in this historical moment, some of the beneficiaries of that inheritance have questioned the starting assumption and identified our world as 'post-secular' that Carl Schmitt's Political Theology would resonate so strongly. That brief but powerful monograph has two passages which, when read together, subvert inherited modes of thinking that distinguish between the political and the religious:

\section{The sovereign is he who decides on the exception. ${ }^{2}$}

All significant concepts of the modern theory of the state are secularized theological concepts not only because of their historical development - in which they were transferred from theology to the theory of the state, whereby, for example, the omnipotent god became the omnipotent lawgiver-but also because of their systematic structure, the recognition of which is necessary for a sociological consideration of these concepts. The exception in jurisprudence is analogous to the miracle in theology. Only by being aware of this analogy can we appreciate the manner in which the philosophical ideas of the state developed in the last centuries. ${ }^{3}$

In these passages, Schmitt blends the political and the religious, or more specifically, the theological. If the modern state offers a secularised form of theology, one way to appreciate the significance of Schmitt's elision is to consider the sovereign's authority analogous to God's, such that miracles are as much a testament to the authority of God as the sovereign's exception is to his. Certainly Schmitt's insights have offered an important vehicle of critique in contemporary political theory. ${ }^{4}$ But Schmitt is not alone in imagining critiques through the lens of theology or religion. In his critique of universal history in the midtwentieth century, Karl Löwith traced the specifically Christian content in historical

2. Carl Schmitt, Political Theology: Four Chapters on the Concept of Sovereignty, trans. George Schwab (Chicago, IL: University of Chicago Press, 1985), p. 5.

3. Schmitt, Political Theology, p. 36

4. Wendy Brown, Walled States, Waning Sovereignty (New York: Zone Books, 2014); Paul Kahn, Political Theology: Four New Chapters on the Concept of Sovereignty (New York: Columbia University Press, 2011). 
narratives of progress: 'We of today, concerned with the unity of universal history and with its progress toward an ultimate goal or at least toward a "better world", are still in the line of prophetic and messianic monotheism; we are still Jews and Christians, however little we may think of ourselves in those terms. ${ }^{5}$ One can certainly take issue with Lowith's claim about the religious content of historical narrative, ${ }^{6}$ but that he nonetheless did

to appreciate Schmitt's contribution as part of a broader intellectual critique.

This reading of politics through theology raises a dilemma, especially for a project devoted to thinking across the Islamic and Christian traditions. For Schmitt and others, the backdrop of theology that animates the political is all too often a thin account of a Protestant theology, and in particular a voluntarist Protestant theology. This Protestant genealogy in the formation of political theology need not preclude the kind of engagement anticipated by the editors of this project. But it does demand our attention, especially if to start from the secularist pretensions of political science for insance. If subversion (or perhaps more politely, provincialisation) is what this engagement seeks, then the provincialising needs to be multidirectional: in this case, it needs to attend to the secular presumptions that often inform the ambit (and study) of the political, as well as the Protestant presumptions that often inform the ambit of the theological (or at least Schmitt's conception of the theological). Such provincialisation calls out for a more robust inquiry into the work theology is doing in the realm of the political.

One way to explore such multidirectional provincialising is to imagine 'theology' in of a more robust voluntarism. An analysis of Schmitt's theology of politics will reve This is perhaps not entirely surprising given his own Catholic rearing. But whether he This is perhaps not entirely surprising given his own Catholic rearing. But whether he reads sovereignty as Protestant or criticises it from a Catholic standpoint, we can nonetheless re-read his account of political theology in terms of a monotheistic divine volunDoing so, as this article suggests, will provide a bridge across the chasm left by

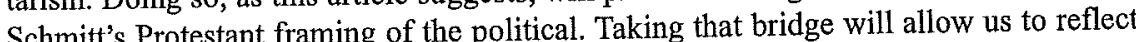
broadly about both the politics of different religious traditions and the theologies that animate political behaviour today. To tease out where this bridge can take us, the article will conclude with an analysis of reformist debates in Islamic law and the practice of treaty reservations in international law.

\section{The Voluntarism of Political Theology}

While Schmitt himself was raised Catholic, ${ }^{7}$ there are moments throughout his Political Theology where the sovereign God tracks a Protestant theology. ${ }^{8}$ This Protestant

5. Karl Löwith, Meanings in History (Chicago, IL: University of Chicago Press, 1949), p. 19.

6. See for instance, Hans Blumenberg, The Legitimacy of the Modern Age, trans. Robert $M$ Wallace (Cambridge, MA: MIT Press, 1985).

On Schmitt's analysis of Roman Catholicism as a counter to the Protestant formation of the state, see Carl Schmitt, Roman Catholicism and Political Form, trans. G. L. Ulmen (London: Greenwood Press, 1996).

This is not to suggest that Schmitt endorsed this Protestant form of the political. For Schmitt, the Protestant ethic of which Weber wrote so compellingly contributed to a politics, conception of the theological, and its secularised refashioning in terms of the sovereign, is already documented by scholars of Schmitt. Tracing that Protestant vision will not preoccupy us here. Of interest, though, is appreciating how that Protestant approach to theology reveals theology as monotheistic voluntarism. While many have also written on theological voluntarism, defending one account or another is not the aim of this article. Rather, following Mark Murphy's general characterisation, I broadly consider 'theological voluntarism' as a view that the moral status of certain entities and acts are by virtue of a divine command ${ }^{9}$

For Schmitt, the sovereign God takes political form in the 'one who acts as his acknowledged representative on earth, or the emperor, or prince, or the people, meaning those who identify themselves directly with the people'.$^{10}$ In this line God is made manifest through a single and singular representative (e.g. prince, emperor). Moreover, where Schmitt gestures to a sovereignty informed by the plurality of the people, it is still a sovereignty exercised by one who identifies 'directly' with the people without intercession or intervention of a priestly class. The direct identification between the sovereign and the people provides a political translation of sola scriptura. Sola scriptura, on this reading, not only characterises the relationship between the believer and God, but also creates the conditions for understanding the sovereign's relation to his subjects in liberal (if not atomised) fashion.

To be sovereign is to be the 'highest, legally independent, underived power'.11 The sovereign is supreme, unrestricted and unmitigated. The state, just as God, is viewed as 'one organ', an 'abstract person', a 'unicum sui generis' - not a disaggregate-able entity, but instead a singular, unique and unified authority. ${ }^{12}$ Much like the omnipotent, voluntarist God, the state is the omnipotent lawgiver that remains utterly 'invisible'. ${ }^{13}$ The enormity of this position is reflected in the sovereign exception itself. If the sovereign is he who exercises the exception, the exception 'is principally unlimited authority, which means the suspension of the entire existing order'. ${ }^{14}$ Unlimited authority speaks to the omnipotence of a sovereign, who like a voluntarist God who employs miracles, can even subvert the accepted state of order.

economics and aesthetics of the private and personal that weakened the European order. Cf. John MacCormick, '[Review essay] Political Theory and Political Theology: The Second Wave of Carl Schmitt in English', Political Theory 26.6 (1998), pp. 830-54, at p. 832

9. Mark Murphy, 'Theological Voluntarism', The Stanford Encyclopedia of Philosophy (Winter 2014), Edward N. Zalta (ed.), online: http://plato.stanford.edu/archives/win2014/entries/voluntarism-theologica1/ (accessed 12 June 2015); idem, 'Divine Command, Divine Will, and Moral Obiigation', Faith and Philosophy 15.1 (1998), pp. 3-27.

10. Schmitt, Political Theology, p. 10.

11. Schmitt, Political Theology, p. 17.

12. Schmitt, Political Theology, p. 39. One might read this line of Schmitt through the Islamic theological debates on the attributes of God (șfät Alläh), which were often concerned with preserving the unity (tawhīd) of God, as opposed to constituting such attributes as co-eternal with God, or even making God disaggregateable.

13. Schmitt, Political Theology, p. 38

14. Schmitt, Political Theology, p. 12 


\section{Theological Voluntarism as Critique}

To read Schmitt's political theology as voluntarist offers a form of critique that questions the secular tendencies that often animate, inform and construct the social sciences, while at the same time avoiding the Protestant parochialisms that inform Schmitt's analysis. ${ }^{15}$ For instance, in a recent essay in Dissent, Michael Walzer queries how the political left might better engage and respond to the violent extremism of Islamist political groups. Chastising the left for its political correctness against the onset of Islamophobia, he admits a fear of what he terms 'Islamic zealots' because, as he writes, 'the Islamic world at this moment in time (not always, not forever) is especially feverish and fervent'. As much as he castigates Islamophobia as religious intolerance, he also wants to preserve for the left the space for 'legitimate criticisms ... not only of Islamic zealots but also of Islam itself-as of any other religion'. ${ }^{16}$

Walzer recognises, however, that the left has not often understood religion; correspondingly he argues that ' $[\mathrm{t}]$ he appeal of religious doctrine and practice is obvious today, and we need to understand it if we are to persuade people that religious zealotry is frighteningly unappealing'. ${ }^{17}$ But what does it mean to understand these doctrines, at least intellectually speaking? For Walzer it means distinguishing between zealots such as 'Hasan al-Banna and Sayyid Qutb in Egypt or Mawlana Mawdudi in India' on the one hand, and 'the great rationalist philosophers of the Muslim past and the liberal reforms of more recent times'. ${ }^{18}$ This type of intellectual engagement, though, is obvious for its overt politics; and perhaps that is the virtue of Walzer's prescription for the left. But it also presumes erroneously that the so-called 'zealots' and the 'rationalist philosophers' make sense as reference points for thinking about and through Islam. Yes, al-Banna, Qutb and Mawdudi were popular and populist in their reach, but the scope of their influence is inversely matched by the marginality of rationalist philosophers in the construction of an Islamic Sunni 'orthodoxy'. To presume philosophy is the appropriate intellectual vehicle to critique 'Islamism', though, has less to do with the terms of debate Islamist parties actually utilise. Islamist groups often rely on the Islamic disciplines of theology (kaläm, 'aqīda) and law ( $\operatorname{shari}^{\dagger} a$, fiqh), none of which privilege the Muslim philosophical tradition. Instead, Walzer's intellectual prescription reveals a certain parochialism about knowledge and the social soiences that inhere in Walzer's 'left'. Indeed, Walzer's prescription reinstantiates the secularism of 'critique' that Talal Asad, Wendy Brown, Judith Butler and Saba Mahmood question. Given their interrogation of the presumed secularity of critique, an inquiry into Islamic voluntarist theology will not only allow us to control for the Protestant geneaology of Schmitt's political theology, but also will illuminate how we might provincialise academic analysis and critique in the

15. For an analysis of the secular assumptions that inform 'critique', see Talal Asad, Wendy Brown, Judith Butler and Saba Mahmood, Is Critique Secular?: Blasphemy, Injury and Free Speech (New York: Fordham University Press, 2013).

16. Michael Walzer, 'Islamism and the Left', Dissent Magazine (Winter 2015), online: http:// www.dissentmagazine.org/article/islamism-and-the-left (accessed 12 June 2015).

17. Walzer, 'Islamism and the Left'.

18. Walzer, 'Islamism and the Left'. humanities and social sciences, which all too often perpetuate the Protestant framing of
the 'religious'.

For the purpose of this article, I will focus on Islamic voluntarist theology in broad terms. There are others more capable to address debates within Protestant theology on voluntarism and its competitors, as well as others devoted to particular accounts of Islamic voluntarist theology. Here, I want to address the broad contours of Islamic vol untarist theology in order to explore the scope of critique (others might say 'dissent') of the political. Elsewhere, I have addressed divine voluntarism in terms of dissent') of logical debates on free will and determinism, as well as juridico-theological debates on natural law. ${ }^{19}$ I will summarise that discussion here briefly, in order to give content to an Islamic voluntarism, and to avoid distracting from the main thrust of this article's argument. $^{20}$

Among the various features of an Islamic voluntarism is an understanding of the God of Islam. As much as Islamic tradition recognises Allah as the God of Christianity and Judaism, it also posits a God who is generally understood as omniscient, omnipresent and all-powerful. As L. Gardet recounts, certain Qur'anic themes about God predominate: 'God of creation, judgment and retribution ... He creates what He wishes ... by His command (amr), by the kun ("Be!") which causes existence ... He is the bestower of all good, the supreme judge (hakim) and the "justest judge" who enjoys "unlimited sover eignty (rububiyya) over His creation"', 21 God is 'sovereign judge and king (malik). God, [u]nique and [o]ne in Himself ... God is thy Lord ... omnipotent and merciful ... Lord of the worlds ... in His unquestioned omnipotence and His forgiving benevolence'.22 This image of God gives credence to a voluntarist account of theology in Islam in which God is imagined as commander and legislator.

This is not to suggest that voluntarism was unchecked or uncontested in early Islamic intellectual history; indeed, it certainly was, with important implications for a philosophy of law. One contested theological site in which voluntarism is especially pronounced concerns the nature of God's justice. Muslim theologians historically debated the justice of God (' $a d l$ ). Some argued that God only acts in a manner that is just, thereby suggesting that there is a rational standard of justice that is external to God and by which God
abides.

But to argue that God is held to a standard external to God's will undermines the omnipotent, all-knowing nature of God. Indeed, this claim vexed voluntarists, who argued instead that whatever God requires is therefore just. Needless to say, scholars

19. See, for example, Anver M. Emon, Islamic Natural Law Theories (Oxford: Oxford University Press, 2010); Anver M. Emon, Matthew Levering and David Novak, Natural Law: A Jewish, Christian and Islamic Trialogue (Oxford: Oxford University Press, 2014), pp. 144-87.

20. For more developed analysis than is possible here, see Tilman Nagel, The History of Islamic Theology: From Muhammad to the Present, trans. Thomas Thornton (Princeton, NJ: Markus Weiner Publishers, 2000); W. Montgomery Watt, The Formative Period of Islamic Thought (Oxford: Oneworld Publications, 1998).

21. L. Gardet, The Encyclopaedia of Islam, 2nd ed., 12 vols. (Leiden: Brill, 1960-2005), s.v. 
have criticised this view for rendering morality as utterly arbitrary. ${ }^{23}$ But in a curious move, voluntarist theologians both anticipated and avoided such a charge. Voluntarists in Islam subsequently argued that, though God is omnipotent, God nonetheless created the world in a manner that corresponded with a certain standard of justice-akin to the justice proposed by the first group. But, voluntarists argued, God did not conform to this account of justice because of some external standard to which he had to conform. Rather, he did so out of his grace and mercy $(f a d l, r a h m a)$. In other words, the voluntarist account in Islamic thought did not yield to the critique of arbitrariness so readily. They adopted a voluntarism that preserved God's omnipotence while asserting that God nonetheless has acted in a certain way out of grace and mercy. The resort to grace and mercy not only allowed voluntarists to avoid the charge of moral arbitrariness, but also preserved God's omnipotence: God can still change his mind. It just so happened, argued these voluntarists, that there is no evidence that God has in fact changed his mind.

Importantly, this voluntarist account gradually became associated with certain theological schools in Sunni Islam, in particular the Ash'ari school of theology. Ultimately, the Ash'ari school of theology became dominant and defined the parameters of theological orthodoxy. ${ }^{24}$ As George Hourani has noted already, Ash'arī voluntarism 'prevailed in most learned circles of classical Sunnite Islam, a result which had far-reaching consequences in law and other spheres of Islamic civilization'. ${ }^{25}$ Taking into account his understanding of the Islamic intellectual tradition, Hourani offers distinctively theologi$\mathrm{cal}$ reasons for this construction of Sunni 'orthodoxy'. Voluntarism, he argued, allowed one to posit the omnipotence of God in part by emphasising the utter dependence of humanity on God. Importantly, that theological dependence upon a just God becomes the enabling condition for legal obligation to the shari ${ }^{-} a{ }^{26}$ In the register of justice, theological voluntarism views justice as obedience to the law; in this fashion, justice is less about limits on God and entirely about limits on human action in the guise of legal obligation. ${ }^{27}$

This voluntarist understanding of God defined Sunni orthodox theology historically, and animates how Muslim thinkers imagine God today. For example, in his Milestones, Sayyid Qutb describes God's creative force in voluntarist fashion. Remarking on the state of ignorance (jāhiliyya) that the Prophet Muhammad preached against, Qutb posits the utter sovereignty of God as the inherent message the Prophet brought to humanity.

23. Matthew C. Jordan, 'Theism, Naturalism, and Meta-Ethics', Philosophy Compass 8.4 (2013), pp. 373-80, at p. 374 .

24. M. Brett Wilson "The Failure of Nomenclature: The Concept of "Orthodoxy" in the Study of Islam', Comparative Islamic Studies 3.2 (2007), pp. 169-94, at p. 171, who insightfully calls into question the use of the term 'orthodox' in the study of Islam.

25. George F. Hourani, Reason and Tradition in Islamic Ethics (Cambridge: Cambridge University Press, 1985), p. 57. See also Mohammad Fadel, 'The True, the Good and the Reasonable', Canadian Journal of Law and Jurisprudence 21 (2008), pp. 5-70, at p. 22, who claims that the Ash'ari theological tradition represents Sunni orthodoxy.

26. Hourani, Reason and Tradition, p. 65.

27. Hourani, Reason and Tradition.
This Jähiliyya is based on rebellion against God's sovereignty on earth. It transfers to man one of the greatest attributes of God, namely sovereignty ... Only in the Islamic way of life do all men become free from the servitude of some men to others, and devote themselves to the worship of God alone, deriving guidance from Him alone, and bowing before him alone. ${ }^{28}$

For Qutb, the universe and all its bodies are organised pursuant to a divine voluntarism that dictates all:

Behind this universe there is a Will which administers it, a Power which moves it, a Law which regulates it. This Power keeps a balance between the various parts of the universe and controls their motions; thus they neither collide with each other nor is there any disturbance in their system, nor do their regular motions come to a sudden stop nor do they become disorganized This will continue as long as the Divine will wishes it to continue. The whole universe obedient to God's Will, His Power and His Authority; it is not possible for it to disobey the Divine Will and its ordained law for a single moment, ${ }^{29}$

But so too are human beings subject to this sovereignty, assuming they understand and abide by an Islamic way of life. For Qutb, the Islamic way of life, embedded in the declaration of faith that there is no god but God (lā ilăha illä Alläh) implies that there is 'no sovereignty except God's, no law except from God, and no authority of one man over another, as the authority in all respects belong [sic] to God' ${ }^{30}$ Qutb's influence on various Islamic movements is both well documented and the Gud $\cdot^{30}$ Qutb's influence on variNonetheless, his contrast between $j$ ah hiliyya and the subject of considerable polemic. tarist theology framed in terms of God's sovereignty, $W$ humanity's obedience to that divine will.

Thinking with Schmitt's political theology, but beyond his Protestant frame of the theological, we can consider the implications of thinking conceptually with 'voluntarism' for a critique of politics. Scholars of Islamic political thought have noted various strands of political quietism. But to read politics through the lens of voluntarism is to query whether and to what extent theology intersects with the political and may even constitute it. For instance, the Qur'an states: 'O you who believe, obey God, and obey the messenger and those in authority over you (wa-uli-l-amr minkum)' ${ }^{31}$ The verse seems to espouse a politics of obedience, which happens to parallel the obedience of voluntarist theology. Moreover, historians of Islam have insisted that there is a powerful political ethic of deference to those who rule. Writing in the wake of the Iranian Revolution of 1979, Cudsi and Dessouki summarise an inherited view of Islamic politics:

In traditional Muslim thought, while political power was an essential function of the Prophet and his legitimate successors, true sovereignty in the umma rested only with God as the source of all authority. Muslim rulers, like all other Muslims, were equally called upon to submit to 28. Sayyid Qutb, Milestones (New Delhi: Islamic Book Service, 2001; repr. 2005), p. 11 [No
translator specified].

29. Qutb, Milestones, p. 87.

30. Qutb, Milestones, p. 26 31. Qur'an $4.59\left(a l-N i s \bar{a}^{3}\right)$. Of course one could argue that 'those in authority' must also satisfy
certain conditions to deserve obedience. 
God's will, and accordingly the shari $a$ was established as the supreme authority in Muslim society. In this view of things, the ruler of the umma was thus responsible to God and his own conscich he ruled. By implication then, the first duty of the conscince alone for the way in which he rive nor community towards the ruler was one of obedience. But this obedience was neither passive no without conditions. The duty of obedience held so long as the ruler ordered nothing which wa contrary to ... the shari $a$. In later periods ... this concept of political obligation had undergone an in absolute duty. It was henceforth argued that even an unjust ruler was better than none at all..$^{32}$

In this brief passage a voluntarist theology of obedience begets a politics of obedience and subservience. For instance, Michael Cook $^{33}$ associates political activism with an Arab tribalism that made possible the active spread of an Islamic empire. But as that empire grew, and Islam became the organising principle of the polity (as opposed to an Arab tribalism), a voluntarist theology preserved the political status quo, especially as the ruling elite and those subject to their authority became farther removed from each other. As Cook teasingly writes, "if politics is none of your business, you had better keep out of it'. ${ }^{34}$ Interestingly, Cook describes Islam as a political religion in which ' $u m m$ m and imamate are at once political and religious conceptions with an ongoing significance in Islamic society - a situation to which no real equivalent can be found in Christianity' ${ }^{35}$ But on a Schmittian reading, Cook's distinction between Islam and Christianity reveals his uncritical attitude towards Christianity and its naturalisation through secular political institutions. On the other hand, Khaled Abou El Fadl criticises Cook by asking why Muslim jurists developed a jurisprudence of rebellion (bugha), which reduced penalties for rebels against the ruling regime, if quietism was pervasive. ${ }^{36}$ But as Abou El Fadl writes, rebels were entitled to reduced penalties if they could show, among other things, that they had a certain military force or power ( $u w w a$, shawka). But the fact that a rebellion doctrine exists does not necessarily preclude a quietist politics by virtue of a voluntarist theology. Rather, a voluntarist reading of politics might render rebels immune to prosecution the larger and more extensive their military capacity. The greater their miliprosecution the larger and more extensive their mikelihood they can exercise sovereign authority, and thereby render their designation as 'rebels' suspect on a voluntarist account of politics.

\section{Voluntarism as Political Lens: Islamic Legal Reform and the Limits of Pacta Sunt Servanda}

One might argue that the debates on quietism and activism reflect a political analysis that is (or ought to be) separate and distinct from the theological. But the critical stance

32. Alexander S. Cudsi and Ali E. Hillal Dessouki, 'Introduction', in Alexander S. Cudsi and Ali E. Hillal Dessouki (eds.), Islam and Power (Baltimore, MD: Johns Hopkins University Press, 1981), p. 9.

33. Michael Cook, 'Activism and Quietism in Islam: The Case of the Early Murji' $a$ ', in Cudsi and Dessouki (eds.), Islam and Power, pp. 15-23.

34. Cook, 'Activism and Quietism in Islam, p. 22.

35. Cook, 'Activism and Quietism in Islam, p. 21 .

36. Khaled Abou El Fadl, Rebellion and Violence in Islamic Law (Cambridge: Cambridge University Press, 2001). adopted here through voluntarism views both the political and the theological as deeply inter-related, if not mutually constitutive.

As many have shown, Islamic political history and theological history often inspired each other. The sectarian divide between the Shi' $a$ and the Sunnis originated in a dispute about rightful and legitimate leadership of the nascent Muslim community. The premodern theological dispute on the createdness of the Qur'an was later a point of provocation that pitted caliphal authority against scholarly authority during the reign of al-Marmūn. As much as the political might be conceptually separable from the theological, that does not preclude reading them together as mutually constitutive. The implications of reading them together, I argue, may be profound for the field of Islamic law, in particular when considering the acceptable range of the legally possible and intelligible. For example Mohammad Fadel argues against certain forms of 'historicism' as a method of feminist critique of gendered rules. He argues that any historicism that relies on a progressive history of cultural and moral change threatens to 'suspend the effectiveness of various Qur'anic legal provisions' and by implication suggests 'that revelation is imperfect'. ${ }^{37}$ The implication that revelation is imperfect, argues Fadel, would create difficult theological problems for Sunni Muslims. He does not explain why such problems would arise; he simply asserts that they would arise and become obstacles to a programme of gender egalitarianism. One can imagine, though, that a voluntarist theology in which God is omnipotent and all-knowing could not tolerate any argument that might call into question that omnipotence and divine foresight. An all-knowing, omnipotent God, it might be argued, would be unbounded by the constraints of time, and presumably would account for changes in morality and value in crafting his revelation to humanity.

This theological sensibility may also explain why Tariq Ramadan, a well-known European Muslim reformist scholar, has argued against applying the Qur'anic corporal punishments on crimes such as theft and fornication. Importantly, he does not argue against the verses themselves or in any way deny their validity as having divine legislative import. Rather he calls for a moratorium on their application. 'All the ulama (scholars) of the Muslim world, of yesterday and today and in all the currents of thought, recognise the existence of scriptural sources that refer to corporal punishment (Qur'an and Sunna), stoning of adulterous men and women (Sunna) and the penal code (Qur'an and Sunna). ${ }^{38}$ For him, the question is how one infers divine legislative intent. He argues that premodern Muslim jurists created so many pre-conditions to applying these corporal sanctions that the punishments were 'almost never applicable'. They served a deterrent function, rather than a retributive one. But in the modern Muslim majority state, they are applied extensively and without appropriate protections for those who are subjected to

37. Mohammad Fadel, 'Is Historicism a Viable Strategy for Islamic Law Reform? The Case of "Never Shall a Folk Prosper who have Appointed a Woman to Rule Them"', Islamic Law and Society 18 (2011), pp. 131-76, at p. 136

38. For the moratorium, see Tariq Ramadan, "An International Call for a Moratorium on Corporal Punishment, Stoning and the Death Penalty in the Islamic World', TariqRamadan.com, 5 April 2015, online: http://tariqramadan.com/blog/2005/04/05/an-international-call-formoratorium-on-corporal-punishment-stoning-and-the-death-penalty-in-the-islamic-world/ (accessed 12 June 2015). 
these punishments. In other words, the modern state has instrumentalised these criminal sanctions to bolster their legitimacy and applied them in contexts that are dubious-from an Islamic legal standpoint-at best. His call for a moratorium therefore is as much a critique of the modern state as it is a recognition of the wide-ranging debate on the application of these punishments.

Ramadan is careful to note that his call for a moratorium is not intended to disrespect the Qur'anic verses or subvert them in any way. Rather as he notes, 'the opposite is true: all the legal texts demand to be read in light of the objective intended to justify them (al-magāsid)'. Rather than adopting a historicist reading of the Qur'an, a literalist one, or something in between, Ramadan wants to create a space for debate, which is what his call for a moratorium provides. His moratorium is a pragmatic solution that, on a voluntarist reading, piously justifies halting any application of the $h u d \bar{u} d$ without actually taking a stance on or against the verses themselves.

The piety of his position is premised upon a voluntarist assumption about God's sovereignty - an assumption that critically informs how he interprets God's word and decree. If interpretation introduces subjectivity into any analysis, a voluntarist reading must construe the meaning of God's words in a manner that maximises God's sovereignty. Canons of construction, when read through a voluntarist lens, can be better appreciated as controlling for subjectivity in the service of God's sovereignty.

For instance, to privilege the 'plain meaning' ( $z \bar{a} h i r)$ of the text as presumptively conveying the legislator's intent (and thereby precluding further analysis of external evidence) pays homage to the legislator's sovereign authority by undercutting the interpreter's agency. This presumption about meaning serves the sovereign by maximising compliance among reading subjects. If Ramadan wanted to contest the meaning of the relevant Qur'anic verses by shifting the canons of construction, he would need to offer a theology of God that allows variances in reading protocols. The piety of such a call would be hard to uphold unless he and his readers were also committed to a non-voluntarist theology of God. In this case, he might escape irascible critique given his more vituperative critique of the modern state. Through his overt critique of authoritarian politics, he can bypass a theological discussion about God's sovereignty by reference to the abuse of a different order of sovereignty. Ramadan's call for a moratorium exudes piety in large part because he can appear as if he is upholding the sovereignty of God by chastising the voluntaristic whimsy of the modern state. But at no point has he left the frame of voluntarism in his call for a moratorium. The voluntarism of God and the state remain constant in his call for 'pause'. If he went beyond this voluntarist frame and, for instance, adopted a historicist bent-one that might historicise corporal punishment generally, ${ }^{39}$ and thereby qualify the transcendence of the verse- he would presumably be accused of threatening the timeless transcendence of the Qur'anic message, and the omnipotence of a God who is all-knowing across the millennia.

39. See, for instance, Michel Foucault, Discipline and Punish: The Birth of the Prison, trans. Alan Sheridan, 2nd edn (New York: Vintage Books, 1995).

\section{International Law and the Limits of Pacta Sunt Servanda}

Reading Schmitt's political theology as voluntarist, while parochialising it by reference to Islamic theological voluntarism, offers a critical vantage point to reflect on states and state practices. For illustration, we will consider the practice of state reservations when ratifying international treaties. For instance, when Muslim majority countries ratify human rights treaties, they often include reservations that invoke $\operatorname{sharī}^{-} a$ to limit their obligations under the treaty. Human rights activists criticise Muslim states for this practice, considering such ratifications as partial or insincere. But the practice of reservations is not unique to Muslim majority countries. Indeed, all states are at liberty to agree to a convention while also asserting limits to the scope of their responsibility under the convention.

International lawyers face interpretation problems when they consider whether and to what extent a state that has ratified an international convention is abiding by the terms of the convention. Moreover, invoking the Vienna Convention on the Law of Treaties, they might even argue that a country's reservations to a treaty so undermine the aim and objectives of the treaty that the ratification is invalid or of no effect. But whether one relies on the Vienna Convention or its de facto commentary, the International Law Commission's 2011 Guide to Practice on Reservations to Treaties, ${ }^{40}$ to criticise reservation practices, neither change the fact that states can, will and ought to be able to insert reservations into treaties. Certainly there are limits to the scope of such reservations; indeed, signatories must be held to the well-established international law principle of pacta sunt servanda that agreements must be kept. But reading this principle through theological voluntarism reveals reservation practices as an exercise of the sovereign exception. As much as pacta sunt servanda aims to create an orderly system for international relations, it is ultimately premised upon the consent of states. As the Soviet scholar I. I. Lukashuk remarked, in a comparative reflection on pacta sunt servanda, '[1]ike all other rules of international law, the principle of good faith fulfillment of obligations derives from, and is kept in force by, the general consent of the states'. ${ }^{11}$ But if the consent of states is centrally significant to this principle of international cooperation, then pacta sunt servanda on a voluntarist reading situates the state as a political analogue to the divine legislator and commander. To do so displaces international law from the central role it claims for itself as a vehicle of global ordering and cooperation. As long as the sovereign state remains central to the imagination of international law and its limits, the state shall continue to displace international law as the principal vehicle of law and authority. On this reading, the reservation option is a pragmatic solution within international law to ensure its salience amid the prerogative power of the state. If international

40. M. Milanovic and L. A. Sicilianos, 'Reservations to Treaties: An Introduction', European Journal of International Law 24.4 (2013), pp. 1055-1059. See also the International Law Commission's 'Guide to Practice on Reservations to Treaties' (2011), online: http://legal. un.org/docs/?path=../ilc/texts/instruments/english/draft_articles/1_8_2011.pdf\&lang=EF (accessed 15 December 2015).

41. I. I. Lukashuk, 'The Principle of Pacta Sunt Servanda and the Nature of Obligation under International Law', American Journal of International Law 83 (1989), pp. 513-18, at p. 513. 
legal agreements are premised upon consent of states imagined voluntaristically, it follows that to maximise the scope of international cooperation requires fashioning a ratification process that is more than an all-or-nothing, zero-sum game. The option to insert reservations to international conventions maximises the potential of international cooperation by viewing conventions not so much as an organic whole as much as a set of separable provisions - at least to the extent defined by the Vienna Convention. Reservations provide the international legal community with a pragmatic vehicle by which to register sovereign dissent while achieving maximal agreement. It recognises the sovereign's prerogative to enter, exit or ignore as it seeks to condition such prerogative authority.

Reading pacta sunt servanda and the reservations regime through the lens of a voluntarist political theology ultimately recasts reservations as an attempt to contain the scope of the sovereign exception in a context of general agreement. Or put more critically, the reservation system reflects the illusion of international law's regulatory claims upon the state, when in fact the state remains (at least legally, if not politically) capable of exit at any time. If anything, a voluntarist reading of the reservation system illuminates from a different vantage point the merely pious hope of international law in contrast to the sacerdotal supremacy of the state.

\section{Conclusion}

Taking inspiration from Robin Lovin's counterfactual, this article offers theological voluntarism as a heuristic by which to parochialise Schmitt's own conception of theology, and to open a space for thinking across Christianity and Islam. To read Islamic legal reform as well as international law through a voluntarist heuristic reveals that claims made in the name of Islamic and international law all too often cover operating presumptions that normalise the sovereign and its exceptionalism. The legal reasoning that attends both Islamic and international law all too often reinstantiates a voluntarism that preserves a certain status quo. That status quo, even when the target of reform efforts, remains untouched for as long as voluntarism remains the operative political theological presumption. Consequently, to draw on theological voluntarism in this discussion is to fashion a deeper standpoint of critique of, and thereby dissent from, that status quo.

To appreciate how this theological lens deepens our critique of the status quo, consider as a thought experiment what a non-voluntarist theology of God might look like. For instance, it might depart from a legalistic understanding of God as legislator, and perhaps instead imagine God as poet. If God were conceived theologically as poet, that might alter the way in which we understand the use of words, and the appropriate poetic canons of construction. It may not be that the most literal meaning of the word ought to prevail. Rather, a poetic reading of the Qur'anic text would arguably construe the meaning of words, phrases and sentences in a more open-ended manner, and thereby avoid prioritising as a canon of construction the literal, plain or ordinary meaning. Consequently, if we adopt a poetic hermeneutic, then even the use of the literal in an imperative voice need not be read literally as a command or directive. Indeed, on a poetic theology of God, one might consider a poet's express use of literal meaning as designed to subvert assumed or accepted meanings or understandings. Moreover, on a poetic reading, the intent of the author may not matter as much. Rather, on a poetic reading, what may matter most is the reception of the reader, thereby making reading less a function of authorial intent (or an elite expertise in deciphering that authorial intent) and instead an exercise in democratic voice. This is not the place to develop a poetic approach to political theology. Rather, in the spirit of this response essay, this thought experiment is meant to provoke the reader to consider alternatives that have not always found an easy fit within the inherited ways of thinking about religion or politics or both. At the very least, the contrast between a voluntarist approach to political theology and a poetic one reveals the stakes inherent in adhering to voluntarism as a defining feature of law and politics. 